University of Nebraska - Lincoln

DigitalCommons@University of Nebraska - Lincoln

2008

\title{
Comparative Pollination Biology of Sympatric and Allopatric Andean lochroma (Solanaceae)
}

Stacey DeWitt Smith

University of Nebraska - Lincoln, ssmith19@unl.edu

Steven J. Hall

Ecosystem Sciences Division, ESPM (Berkeley, California), stevenhall@berkeley.edu

Pablo R. Izquierdo

Charles Darwin Research Station

David A. Baum

University of Wisconsin - Madison

Follow this and additional works at: https://digitalcommons.unl.edu/bioscifacpub

Part of the Life Sciences Commons

Smith, Stacey DeWitt; Hall, Steven J.; Izquierdo, Pablo R.; and Baum, David A., "Comparative Pollination Biology of Sympatric and Allopatric Andean lochroma (Solanaceae)" (2008). Faculty Publications in the Biological Sciences. 108.

https://digitalcommons.unl.edu/bioscifacpub/108

This Article is brought to you for free and open access by the Papers in the Biological Sciences at DigitalCommons@University of Nebraska - Lincoln. It has been accepted for inclusion in Faculty Publications in the Biological Sciences by an authorized administrator of DigitalCommons@University of Nebraska - Lincoln. 


\section{COMPARATIVE POLLINATION Stacey DeWitt Smith, ${ }^{2,4}$ Steven J. Hall, ${ }^{2,5}$ BIOLOGY OF SYMPATRIC AND Pablo R. Izquierdo, ${ }^{3}$ and David A. Baum ${ }^{2}$ ALLOPATRIC ANDEAN IOCHROMA (SOLANACEAE) ${ }^{1}$}

Abstract

Field studies were conducted for 15 species of Iochroma Benth. and the nested genus Acnistus Schott to quantify the diversity of pollination systems and to assess the potential contribution of pollinator behavior to the persistence of closely related species in sympatry. We combined measures of pollinator visitation and pollen deposition to estimate the importance of major groups of pollinators for each species, and we calculated proportional similarity in the pollinator assemblage among species. We found that 12 species of Iochroma, encompassing a range of flower colors and sizes, were principally pollinated by hummingbirds and, in many cases, by the same hummingbird species. The remaining species were either pollinated by a mix of hummingbirds and insects (two species) or exclusively by insects (two species). Based on proportional similarity values, the overlap in pollinator assemblages was found to be higher for sympatric species than for allopatric ones, reflecting sharing of local pollinator fauna. However, observations of individual pollinator fidelity, perhaps related to territorial interactions among hummingbirds, suggested that pollinators may still contribute to the reproductive isolation of sympatric congeners. Nonetheless, because interspecific pollen flow does occur, the maintenance of species boundaries in sympatry probably requires postmating reproductive isolating mechanisms.

Key words: Acnistus, flower color, hummingbird pollination, Iochroma, pollen deposition, pollinator importance, pollinator visitation, reproductive isolation, sympatry.

The rich floristic diversity of the Neotropics has often been attributed to the complex and specialized interactions between plants and animals, typically in the form of herbivory or pollination (Faegri \& van der Pijl, 1966; Janzen, 1973; Johnson \& Steiner, 2000). For example, Gentry (1982) noted that the Andeancentered families, such as the Ericaceae, Gesneriaceae, and Campanulaceae, which account for a large proportion of the Neotropical species diversity, are biotically pollinated and often appear to be specialized for particular groups of animals such as hummingbirds or bats (Perret et al., 2001; Luteyn, 2002; Muchala, 2006). While geographical patterns in pollinator specialization have become the subject of debate (Ollerton \& Cranmer, 2002; Olesen \& Jordano, 2002), the largest barrier to understanding the role of pollinators in the diversification of Neotropical taxa remains the paucity of detailed studies of pollination ecology, particularly those that catalog not only the range of visitors but their effectiveness as pollinators (Kay \& Schemske, 2004).

Here, we investigate the pollination biology of Iochroma Benth., an Andean genus of approximately 25 species of Solanaceae (Smith \& Baum, 2006). Several authors (e.g., Lagerheim, 1891; Cocucci, 1999) have speculated that the showy tubular flowers of Iochroma species are pollinated by hummingbirds; however, no previous field studies of pollination exist for this group. While several Iochroma species (e.g., I. fuchsioides (Humb. \& Bonpl.) Miers and I. gesnerioides (Kunth) Miers) are indeed a close fit to the classic hummingbird syndrome flower, namely red, scentless, and tubular, most species vary from this suite of traits, suggesting pollination by other groups

\footnotetext{
${ }^{1}$ The authors gratefully acknowledge support for this study from National Science Foundation (grant 0309310), the Marie Christine Kohler Fellowship, the University of Wisconsin Tinker-Nave Fund, the University of Wisconsin Department of Botany O. N. Allen Memorial Fund, and a postdoctoral fellowship in Evolutionary Genomics and Molecular Evolution from Duke University and the Duke Institute for Genome Sciences \& Policy. We thank W. Quizhpe, A. Rodriguez, V. Zak, and S. Leiva G. for assistance in the field, R. Bleiweiss for help with hummingbird determinations, S. Krauth for higher-level insect identification, C. Rasmussen for determinations of Apidae and Halictidae, R. Jeanne for the determination of Polybia, and R. A. Smith for editing. We thank A. Tye for arranging study of the Galápagos-endemic Iochroma ellipticum. The manuscript was improved by comments from J. W. Boughman, V. Hollowell, D. M. Spooner, K. J. Sytsma, N. Waser, P. Wilson, and two anonymous reviewers.

${ }^{2}$ Department of Botany, University of Wisconsin, Madison, Wisconsin 53706, U.S.A.

${ }^{3}$ Charles Darwin Research Station, Puerto Ayora, Santa Cruz, Galápagos Islands, Ecuador.

${ }^{4}$ Current address: Department of Biology, Duke University, Durham, North Carolina 27708, U.S.A. sds21@duke.edu.

${ }^{5}$ Current address: Ecosystem Sciences Division, ESPM, 137 Mulford Hall \#3114, Berkeley, California 94720, U.S.A. stevenhall@berkeley.edu.
}

doi: 10.3417/2007037

Ann. Missouri Bot. Gard. 95: 600-617. Published on 30 December 2008. 


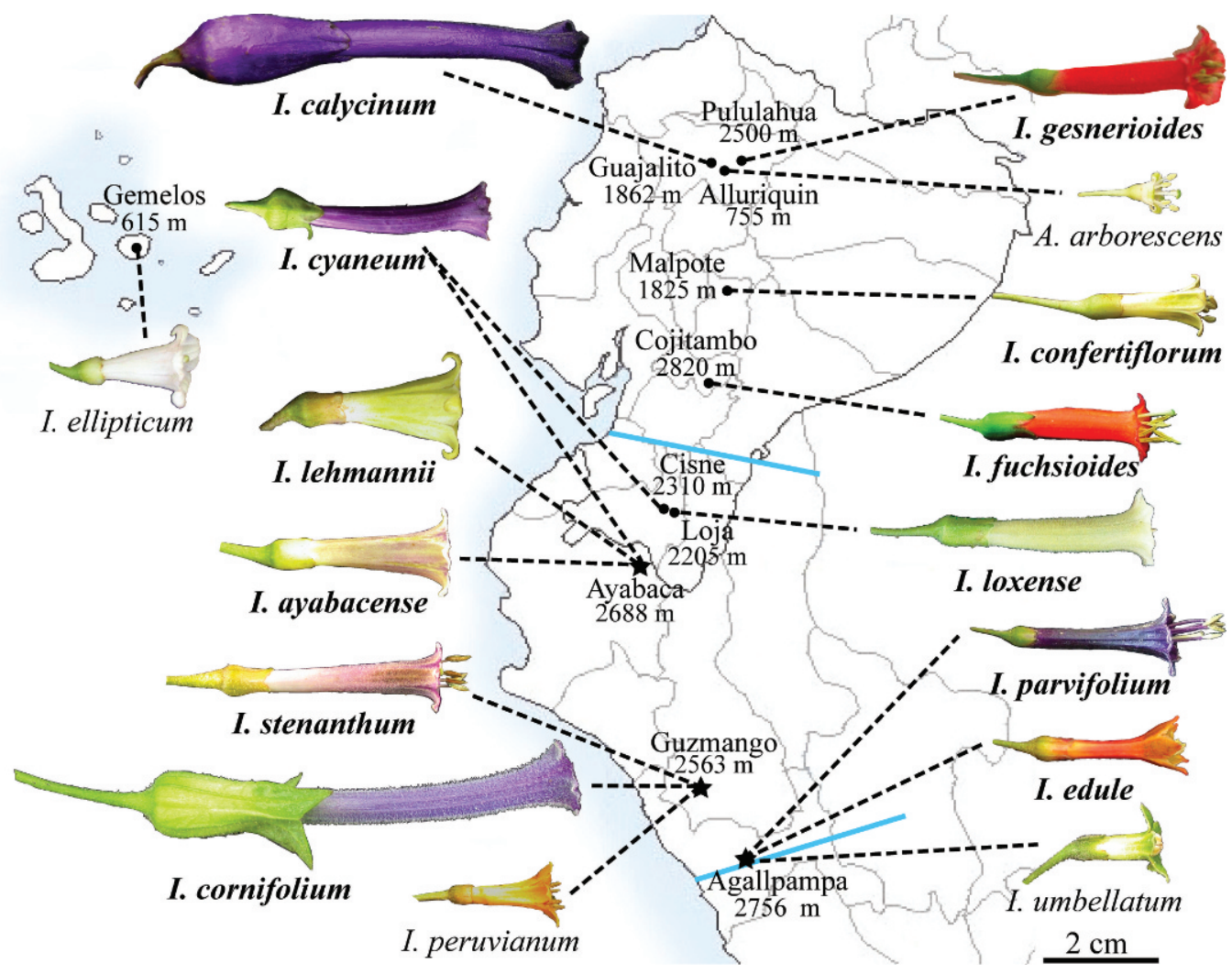

Figure 1. Study sites in Ecuador and Peru in northwestern South America. Country borders are in dark grey, and provinces or departments are bounded in light grey. Approximate boundaries of the Amotape-Huancabamba zone (from Weigend, 2002) are indicated with blue lines. Galápagos Islands (upper left) are not to scale. Study species at each site are indicated with dashed lines, and flowers are shown to scale (bottom right). Sites with sympatric taxa are marked with stars, and the names of the principally hummingbird-pollinated taxa (as determined by this study) are in boldface.

of animals (Fig. 1). For instance, the flowers of $I$. confertiflorum (Miers) Hunz. are greenish white, tubular, and scented, traits more commonly associated with moth pollination (Faegri \& van der Pijl, 1966). Also, many species exhibit the peculiar combination of long, tubular, blue or purple flowers, a combination that does not correspond to any known syndrome (Faegri \& van der Pijl, 1966). Given the diversity of floral morphologies present in Iochroma, we predicted that the composition of visitors and their effectiveness as pollinators would vary substantially between species.

Differences in pollination system among Iochroma species may carry important implications for the maintenance of species boundaries. In some parts of the Andes, Iochroma species occur in sympatry and flower together during the rainy season, creating the potential for interspecific pollen flow. Although some hybrids have been documented in zones of sympatry (Smith \& Baum, 2006), interspecific hybridization is not rampant, and many taxa coexist with no observed hybrid formation (Smith, 2006). Pollinators may contribute to reproductive isolation in areas of sympatry either by forming specialized relationships with particular Iochroma species or by exhibiting constancy during foraging bouts, such that interspecific gene flow is limited (Jones, 1978; Campbell \& Motten, 1985; Waser, 1986).

In the present study, we assessed the specialization of pollinators on 15 Iochroma species and the nested genus Acnistus Schott, and, in areas of sympatry, we examined the importance of pollinator behavior in interspecific pollen flow. In order to characterize the pollination system for each species, we measured pollinator visitation rates and pollen deposition for four major groups of pollinators (hummingbirds [Trochilidae], as well as hymenopteran, lepidopteran, and dipteran insects), and we calculated a composite variable, pollinator importance, for each group. Using the visitation rates for each pollinator, we compared the similarity in pollinator assemblage for allopatric and sympatric species pairs to determine if sympatric 
Published in the Annals of the Missouri Botanical Garden (2008) 95: 600-617.

taxa tend to show more divergence in their pollinator use than is typical for allopatric taxa. Finally, we compiled observations of individual pollinator movements in sympatric areas to examine the possibility of preferential visitation by individual pollinators.

\section{Materials and Methods}

STUDY TAXA

Our taxon sampling of Iochroma represented the range of floral variation within the genus. Iochroma flowers may be red, orange, yellow, white, green, blue, and purple, and all of these colors were included in our study group. Flower form in Iochroma ranges from campanulate to narrowly tubular. Here, the campanulate form is represented by Acnistus arborescens (L.) Schltdl., the sole member of the genus Acnistus (Hunziker, 2001), which is nested within the core clade of Iochroma (Smith \& Baum, 2006). Corolla tube length varies more than eight-fold in Iochroma, and in our study taxa ranges from less than $1 \mathrm{~cm}$ to more than $6 \mathrm{~cm}$ (Fig. 1). Only two Iochroma species (I. ellipticum (Hook. f.) Hunz. and I. confertiflorum) produce any noticeable scent, and both were included here. Their light, sweet scent is very similar to that of their close relative $A$. arborescens, whose scent apparently derives from a mixture of 3,5-dimethoxytoulene, jasmine, anisaldehyde, and methyl anthranilate (Kaiser, 2000).

The selection of study taxa also took into account the recent phylogenetic analysis of Iochrominae (Smith \& Baum, 2006), which indicated that the genus Iochroma is not monophyletic, but is instead divided among three major clades. Eleven of the studied taxa fall into the large core clade of 13 Iochroma species (Smith \& Baum, 2006), which also includes Acnistus arborescens. Outside of this core group of iochromas, we sampled two additional species, I. parvifolium (Roem. \& Schult.) D'Arcy and I. umbellatum (Ruiz \& Pav.) Hunz. ex D'Arcy (Smith \& Baum, 2006). Also, we studied two recently named taxa, I. ayabacense S. Leiva and I. stenanthum S. Leiva, Quipuscoa \& N. W. Sawyer, which appear to be of hybrid origin (Smith \& Baum, 2006). Phylogenetic analyses have suggested that I. ayabacense is a hybrid between I. lehmannii Bitter and I. cyaneum (Lindl.) M. L. Green, and I. stenanthum is probably a hybrid between I. cornifolium (Kunth) Miers and A. arborescens (Smith \& Baum, 2006). Vouchers were collected for all studied populations; these are given in Appendix 1.

STUDY SITES

Iochroma species are mainly distributed in the Andes of Colombia south to Peru, where they occur as sparsely distributed large shrubs or treelets in scrub or cloud forest between 2200 and $2900 \mathrm{~m}$. The greatest species richness occurs in the AmotapeHuanacamba zone at the border of Ecuador and Peru (Smith \& Baum, 2006; Fig. 1). Whereas outside of this zone Iochroma species are typically found in allopatry, geographic ranges frequently overlap within the Amotape-Huanacamba zone, and up to four species can co-occur within a single $1-\mathrm{km}^{2}$ area. A few species pairs (e.g., I. cyaneum and I. cornifolium) hybridize in areas of contact, but many do not (e.g., I. umbellatum and I. edule S. Leiva) (Smith, 2006). There are some differences among taxa in microhabitat preferences (e.g., soil, light, and moisture conditions), but generally, Iochroma species are found in areas of moderate disturbance, such as forest gaps, trails, dry stream beds, or field edges. The 11 study sites were typically located on the outskirts of rural towns or villages, in areas of mixed secondary vegetation and small-scale agriculture; the locations are shown in Figure 1 and listed in Appendix 1.

Iochroma species flower throughout the year, but peak flowering occurs during the rainy season, roughly from December to April in the Andean regions of Ecuador and Peru where these studies took place. Flowering peaks slightly earlier in northern Ecuador (December) than in southern Ecuador and Peru (January to February). During these months, the weather is typically sunny in the morning and cloudy or rainy in the afternoon and evening. Pollinator observations for each species were made over a threeto four-day period during the rainy season; a few studies were extended for a fifth day when extremely rainy conditions persisted for several days or when the overall rate of pollinator visitation was low. The dates of each study are given in Appendix 1. To the extent possible, the pollination studies were conducted in sites that were well within the geographic and altitudinal range of the species and contained many large, flowering individuals (20 to 200). Up to 14 individuals in each population were incorporated into each study (Appendix 1), although the scarcity and/or poor accessibility of some taxa limited the number of available individuals (e.g., four plants for I. peruvianum (Dunal) J. F. Macbr.).

\section{FLORAL BIOLOGY}

Stigma receptivity was judged using the hydrogen peroxide test (Kearns \& Inouye, 1993). Styles were collected from flowers throughout anthesis (from bud to a wilted flower) and dipped in hydrogen peroxide. The youngest stigma to yield a positive result (production of bubbles) was taken to indicate the onset of stigma receptivity. 
Published in the Annals of the Missouri Botanical Garden (2008) 95: 600-617.

Copyright 2008, Missouri Botanical Garden. Used by permission. DOI: 10.3417/2007037.

Volume 95, Number 4

2008
Smith et al.

Pollination Biology of lochroma
Nectar volume was measured with calibrated glass micropipettes, and the percentage of sugar was estimated using a temperature-compensated hand refractometer (QA Supplies, Norfolk, Virginia, U.S.A.) accurate to $0.2 \%$ between $0 \%$ and $32 \%$ sugar by volume. Nectar was extracted by pressing the micropipette into the spaces between the filaments where the liquid accumulates in Iochroma. Samples were taken from first- or second-day flowers (covered with 1-mm mesh bags before anthesis) at 3-hr. intervals from 0700 to $1900 \mathrm{hr}$. Each flower was only sampled once. Flowers were sampled from five to 10 individuals per study population.

VISITATION

Pollinator visits were recorded for two to three days during three observation periods: morning (0600 to $0900 \mathrm{hr}$.), midday (1100 to $1400 \mathrm{hr}$.), and evening (1700 to $2000 \mathrm{hr}$.). Two hours of observations were recorded during each period, but with the time required to move between study individuals, each period spanned $3 \mathrm{hr}$. The time periods were chosen based on previous observations that suggested that these are periods of high pollinator activity. During the studies, the sun rose at ca. $0600 \mathrm{hr}$. and set at $1900 \mathrm{hr}$. Observations were made while sitting 2.5 to $3.5 \mathrm{~m}$ from a subject plant to minimize the distraction of visitors. Both the number of visits to the subject plant and the number of legitimate flower visits (sensu Jones \& Reithel, 2001) were noted. Bird visitors were identified to the lowest possible taxonomic level using field guides and consultation with experts. Visiting insects were collected in ethanol $(70 \%)$ and later identified by comparing them to reference collections at the University of Wisconsin-Madison, the University of Illinois-Urbana, and the Charles Darwin Research Station. All insect specimens were deposited in the University of Wisconsin-Madison Insect Research collection.

Plant and flower visitation rates were calculated from raw observation data by dividing the total number of visits by a given pollinator by the time observed (in flower hours to correct for differences in display size among individuals, sensu Dafni, 1992). Flower hours were calculated from a series of observations ( 1 to $\mathrm{n})$ as follows: $\mathrm{FH}=\left(\mathrm{D}_{1} \times \mathrm{T}_{1}\right)+$ $\left(D_{2} \times T_{2}\right)+\ldots\left(D_{n} \times T_{n}\right)$, where $F H$ equals the number of flower hours, $\mathrm{D}$ is the display size (number of flowers on the plant), and $\mathrm{T}$ equals the number of hours the plant was observed. Visitation rates were calculated both for individual species and for four major groups of pollinators (hummingbirds, as well as hymenopteran, lepidopteran, and dipteran insects). Flower visitation rates were used to compute the proportional similarity (PS) of pollinator assemblages between all pairs of Iochroma species (Schemske \& Brokaw, 1981; Kay \& Schemske, 2003). This measure takes into account both the number of pollinator species shared and their visitation frequency; PS for a pair of plant species is $1-1 / 2 \Sigma\left|\mathrm{P}_{a i}-\mathrm{P}_{b i}\right|$, where $\mathrm{P}_{a i}$ and $\mathrm{P}_{b i}$ are the proportions of the total visitation rate made up by pollinator species $i$ for plant species $a$ and $b$, and differences in $\mathrm{P}_{a i}$ and $\mathrm{P}_{b i}$ are summed across all pollinator species, $1 \ldots i$. PS values range from 0 to 1 , with higher values indicating greater overlap in the pollinator visitation between two species.

\section{INTERSPECIFIC POLLINATOR MOVEMENTS}

We assessed the potential for interspecific pollen flow in sympatry by observing pollinator visitation to individual plants from different species growing side by side. The closest pairs of plants, typically 1 to $5 \mathrm{~m}$ apart, were selected for observation, and movement of the pollinators within the plants and between the plants was recorded. We examined the visitation patterns for bias toward particular Iochroma species by a given pollinator by comparing the expected to the observed number of visits with $\chi^{2}$ analysis (as in Schemske, 1981). Expected values are the number of visits expected if visits are directly proportional to display size. Also, using the observations of the sympatric plant pairs, we compared the number of plant visits that involved movement between species to those that were restricted to one species as an additional measure of pollinator fidelity.

\section{POLLEN DEPOSITION AND POLLINATOR IMPORTANCE}

To measure pollen deposition by different pollinator species, virgin flowers (covered with green or black 1$\mathrm{mm}$ mesh bags before anthesis) were presented to pollinators and then re-bagged after a single visit by a single pollinator. The pollen loads on visited stigmas were compared to stigmas from flowers that were bagged for the duration of the experiment to determine if these species require biotic pollination. Also, we collected and examined stigmas from unbagged flowers to assess the typical pollen deposition for flowers exposed to unlimited visits.

To test for nocturnal pollination, stigmas were collected from flowers that had been bagged during the day but left unbagged at night (1900-0600 hr.). Additionally, for 13 study species (excluding Acnistus arborescens, Iochroma cyaneum, and I. gesnerioides), stigmas were collected from flowers that were bagged at night but unbagged during the day (0600-1900 hr.). Where there were sufficient flowers, all four treat- 
Published in the Annals of the Missouri Botanical Garden (2008) 95: 600-617.

Copyright 2008, Missouri Botanical Garden. Used by permission. DOI: 10.3417/2007037.

ments (always bagged, never bagged, bagged during night only, bagged during day only) were completed for each individual. Styles were removed from flowers that were already open at the beginning of the experiment to ensure that only virgin flowers were included.

Styles from visited or treated flowers were collected 6 to $12 \mathrm{hr}$. after replacement of the bag, fixed in formalin, acetic acid, and alcohol (FAA) for 12 to $24 \mathrm{hr}$. and transferred to ethanol $(70 \%)$ for storage. The fixed stigmas were examined for the presence of germinating pollen grains using a modified version of Martin's (1959) protocol. The styles were soaked in $4 \mathrm{M} \mathrm{NaOH}$ to soften $(10 \mathrm{~min}$.), washed three times in $50 \mathrm{mM} \mathrm{KPO}_{4}$ buffer ( 5 min. per wash), stained with $0.05 \%$ decolorized aniline blue in $50 \mathrm{mM} \mathrm{KPO}_{4}$ buffer for 5 min., squashed on a microscope slide, and viewed under ultraviolet fluorescence microscopy. When the style contained fewer than ca. 100 grains, all were counted. When there were greater than 100 grains, the style was divided into sections (e.g., halves, quarters), and a count from a representative section was used to estimate the total load. Nonfluorescing grains (not germinating and/or not Solanaceae) were excluded from counts. Iochroma species do not differ markedly in pollen morphology, so it was not possible to identify pollen to species. To relate pollen load to ovule availability, the average number of ovules per flower in each species was estimated by counting ovules from enough flowers to bring the standard error to less than $10 \%$ of the mean, when sufficient flowers were available.

Pollen deposition (quality) was combined with visitation rate (quantity) to give an overall estimate of pollinator importance (Waser \& Price, 1983; Schemske \& Horvitz, 1984; Herrera, 1987; Mayfield et al., 2001). Here, the importance of each group of pollinators was calculated as the product of the relative visitation rate and the proportion of available ovules potentially pollinated by a single visit (using the previously described estimates of ovules per flower). If the average number of pollen grains deposited by a single visit exceeded the estimated number of ovules, the proportion was set to 1.0. We used this scaled deposition for two reasons. First, it allowed us to take into account the differences in ovule number and, thus, in potential per-visit effectiveness across study species. Second, this approach accommodates the fact that seed set typically levels off quickly with increasing pollen load (Silander \& Primack, 1978; Kohn \& Waser, 1985), so pollen deposition that greatly exceeds the number of ovules (as observed here for many hymenopterans) is unlikely to result in a proportional increase in fitness.
Results

\section{FLORAL BIOLOGY}

Measurements of stigma receptivity showed that Acnistus and all species of Iochroma, except I. umbellatum, are protogynous. Stigmas are fully receptive when the flowers open, and the anthers dehisce 1 to $3 \mathrm{hr}$. later except in I. umbellatum, in which the anthers are already dehisced when the flower opens. Iochroma flowers open asynchronously throughout the day, but with some tendency toward opening in the morning, and they do not close at night. The stigmas remained receptive until the flowers wilted, two to three days after opening.

Nectar-standing crop varied widely across taxa, but did not show strong diurnal patterns, in large part because of the staggering of flower maturation during the day. For comparison across taxa, we pooled measurements from all sampling times and computed averages for nectar volume and concentration (Table 1). The small-flowered Acnistus arborescens produced the lowest volume of nectar $(0.5 \pm 0.1 \mu \mathrm{l})$ and presented the smallest reward, both on a per-flower and a per-plant basis. The large-flowered Iochroma calycinum Benth. produced the most nectar (38.4 \pm $3.0 \mu \mathrm{l})$, although it did not offer the highest per-flower reward because of its low sugar concentration (14.5 \pm $0.3 \%$ ). The most rewarding species was $I$. loxense (Kunth) Miers due to its high nectar volume (37.0 \pm $2.7 \mu \mathrm{l})$, high sugar concentration $(24.0 \pm 0.5 \%)$, and large display size (120.3 \pm 38.1 flowers per plant).

\section{VISITATION}

Over the course of ca. $264 \mathrm{hr}$. of observation, 47 pollinators were observed legitimately visiting the 16 study species (Appendix 2). Bees and species of flower-piercing birds (Diglossa Chapman [Thraupidae]) were frequent illegitimate visitors, robbing nectar by making holes in the sides of the corollas. These illegitimate visits were not included in visitation rates. Legitimate visitors included hummingbirds (Apodiformes, Trochilidae) and a wide variety of insects from the Hymenoptera, Diptera, and Lepidoptera (Appendix 2).

Hummingbird visits were evenly spread across all observation periods, hymenopteran visits were most common in the midday period (1100-1400 hr.), dipteran visits occurred primarily in the morning (0600-0900 hr.), and lepidopteran visits (mainly moths) were most frequent in the evening period (1700-2000 hr.). Hymenoptera and Diptera visited 2.6 and 2.1 flowers per plant visit, respectively, whereas Lepidoptera visited 4.5 flowers on average and hummingbirds 15.8 flowers. 
Published in the Annals of the Missouri Botanical Garden (2008) 95: 600-617.

Copyright 2008, Missouri Botanical Garden. Used by permission. DOI: 10.3417/2007037.

Volume 95, Number 4

Smith et al.

Table 1. Nectar rewards across study taxa.

\begin{tabular}{lccccc}
\hline \hline \multicolumn{1}{c}{ Species } & $\begin{array}{c}\text { Flowers } \\
\text { sampled }\end{array}$ & $\begin{array}{c}\text { Average nectar } \\
\text { volume }(\mu \mathrm{l}) \pm \mathrm{SE}\end{array}$ & $\begin{array}{c}\text { Average percent } \\
\text { sugar } \pm \mathrm{SE}\end{array}$ & $\begin{array}{c}\text { Average reward per } \\
\text { flower }^{2} \pm \mathrm{SE}\end{array}$ & $\begin{array}{c}\text { Average reward per } \\
\text { plant }\end{array}$ \\
\hline Acnistus arborescens & 16 & $0.5 \pm 0.1$ & $14.4 \pm 2.5$ & $0.1 \pm 0.02$ & $2.3 \pm 0.6$ \\
Iochroma ayabacense & 25 & $11.8 \pm 1.0$ & $22.5 \pm 0.3$ & $2.7 \pm 0.2$ & $459.9 \pm 128.1$ \\
I. calycinum & 26 & $38.4 \pm 3.0$ & $14.5 \pm 0.3$ & $5.7 \pm 0.5$ & $169.3 \pm 63.9$ \\
I. confertiflorum & 37 & $17.5 \pm 1.6$ & $20.9 \pm 0.6$ & $3.8 \pm 0.4$ & $424.4 \pm 148.6$ \\
I. cornifolium & 20 & $37.3 \pm 3.2$ & $18.4 \pm 0.3$ & $6.9 \pm 0.6$ & $603.0 \pm 121.8$ \\
I. cyaneum & 29 & $17.7 \pm 1.9$ & $23.1 \pm 0.7$ & $4.1 \pm 0.4$ & $177.8 \pm 42.6$ \\
I. edule & 28 & $10.9 \pm 1.1$ & $20.7 \pm 0.4$ & $2.3 \pm 0.2$ & $704.7 \pm 167.6$ \\
I. ellipticum & 29 & $1.8 \pm 0.3$ & $7.6 \pm 1.4$ & $0.2 \pm 0.05$ & $10.22^{4}$ \\
I. fuchsioides & 32 & $20.2 \pm 1.8$ & $26.4 \pm 0.7$ & $5.2 \pm 0.4$ & $414.8 \pm 79.7$ \\
I. gesnerioides & 11 & $10.0 \pm 2.4$ & $16.3 \pm 0.66$ & $1.7 \pm 0.4$ & $841.7 \pm 482.2$ \\
I. lehmannii & 26 & $7.0 \pm 0.6$ & $27.2 \pm 0.84$ & $1.8 \pm 0.2$ & $515.3 \pm 229.6$ \\
I. loxense & 30 & $37.0 \pm 2.7$ & $24.0 \pm 0.47$ & $8.7 \pm 0.5$ & $1048.1 \pm 338.6$ \\
I. parvifolium & 17 & $17.5 \pm 1.1$ & $20.0 \pm 0.7$ & $3.5 \pm 0.3$ & $342.6 \pm 133.7$ \\
I. peruvianum & 20 & $6.9 \pm 0.7$ & $21.3 \pm 0.6$ & $1.4 \pm 0.2$ & $122.6 \pm 29.0$ \\
I. stenanthum & 23 & $21.4 \pm 2.5$ & $19.5 \pm 0.4$ & $4.2 \pm 0.5$ & $880.5 \pm 243.7$ \\
I. umbellatum & 32 & $2.2 \pm 0.4$ & $16.4 \pm 0.6$ & $0.4 \pm 0.08$ & $31.1 \pm 17.1$ \\
\hline
\end{tabular}

${ }^{1}$ All values are shown with standard error (SE).

${ }^{2}$ Reward per flower is the product of volume per flower and percent sugar.

${ }^{3}$ Reward per plant is the product of average reward per flower and average display size (Appendix 1).

${ }^{4}$ Variation in display size across the population was not measured in Iochroma ellipticum, thus no standard error was calculated.

Based on relative flower visitation, we classified the species into three broad classes: principally hummingbird pollinated, mixed hummingbird/insect pollinated, and exclusively insect pollinated (Table 2). Taxa for which greater than $75 \%$ of the total visitation was concentrated on a single group of pollinators were considered to be specialized for that group (Fenster et al., 2004). With this criterion, 11 of the study species were considered to be principally hummingbird pollinated (Table 2). Iochroma calycinum had only $65 \%$ hummingbird visitation, but was also classified as principally hummingbird pollinated because most insect visitors were found to be poor pollen vectors (described below; Table 3). Two species, I. peruvianum and I. umbellatum, were visited almost equally by hummingbirds and hymenopterans and were considered to have a mixed bird and insect pollination system. Acnistus arborescens and I. ellipticum were visited frequently by all three groups of insects but no hummingbirds were observed (Table 2), so these two taxa were considered insect pollinated. Thus, we did not observe a diverse array of specialized systems, at least at the level of major pollinator groups.

Iochroma species appeared more divergent in pollination system at the pollinator species level, but these differences may be driven more by geography than by specialization for certain pollinators. As described previously, we calculated the pairwise PS metric from the pollinator visitation rates (Appendix 2) and used these values to assess the overlap in pollinator assemblage among species (Fig. 2). We observed that species with different pollination systems (Table 2) did not have significantly lower proportional similarity than species with the same pollination systems (mean PS $=0.13 \pm 0.02$ vs. $0.18 \pm 0.03$, unpaired $t$-test: $P=0.16$ ). That is, two principally hummingbird-pollinated species did not necessarily show greater overlap in pollinator assemblage than a principally hummingbird-pollinated and an insect-pollinated species. However, species studied in allopatry had lower PS than those in sympatry (mean PS $=0.13 \pm 0.02$ vs. $0.51 \pm 0.10 ; P$ $<0.00001)$ and species living in different regions had significantly lower proportional similarity than those living in the same region (mean PS $=0.08 \pm 0.01$ vs. $0.36 \pm 0.04 ; P<0.00001)$.

\section{INTERSPECIFIC POLLINATOR MOVEMENTS}

To better understand pollinator activity in areas of sympatry, we examined patterns of pollinator visitation to pairs of plants from different sympatric species. Our observations revealed biased patterns for most pollinator species. We observed that the larger hummingbirds (e.g., Coeligena iris Gould and Colibri coruscans Gould) visited the species that provided the greater nectar reward significantly more frequently, in every case with a sufficient sample size (Table 4). The smaller hummingbirds Adelomyia melanogenys Fraser, Myrtis fanny Lesson, and Polyonymus caroli Bourcier often showed 


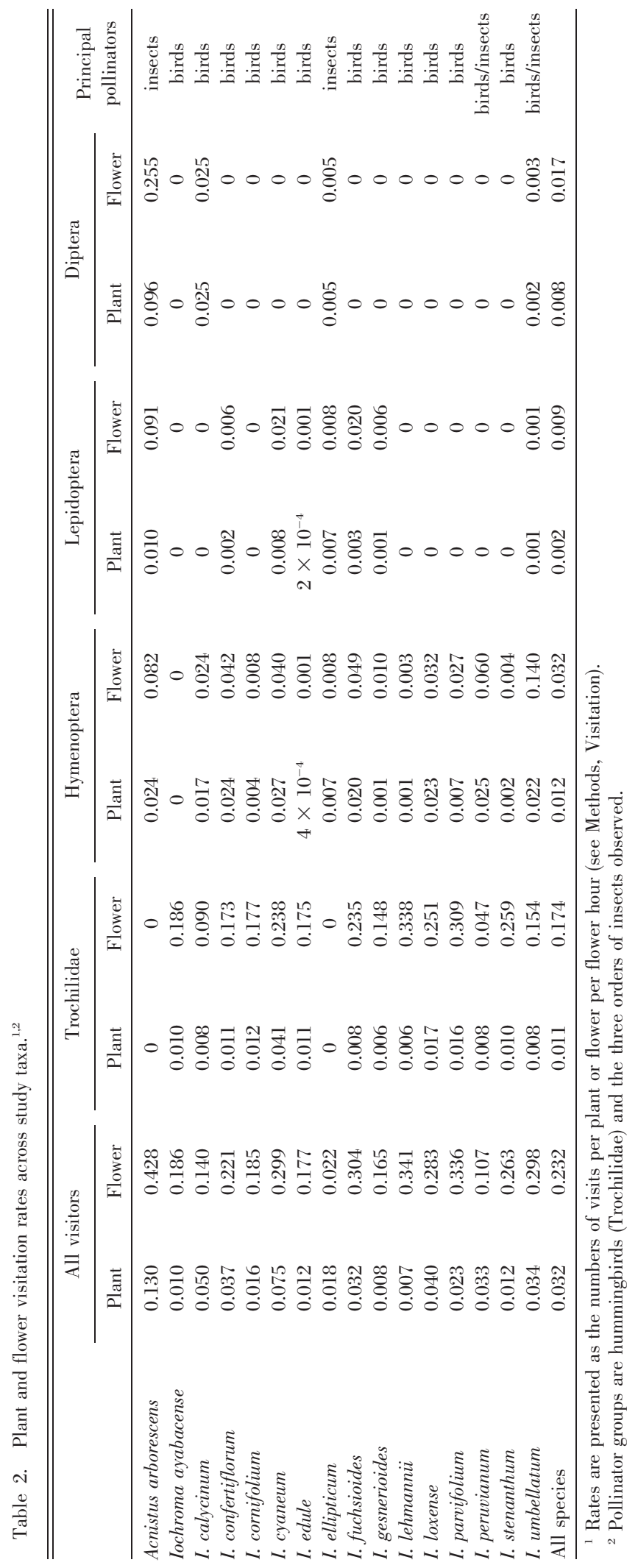


Published in the Annals of the Missouri Botanical Garden (2008) 95: 600-617.

Copyright 2008, Missouri Botanical Garden. Used by permission. DOI: 10.3417/2007037.

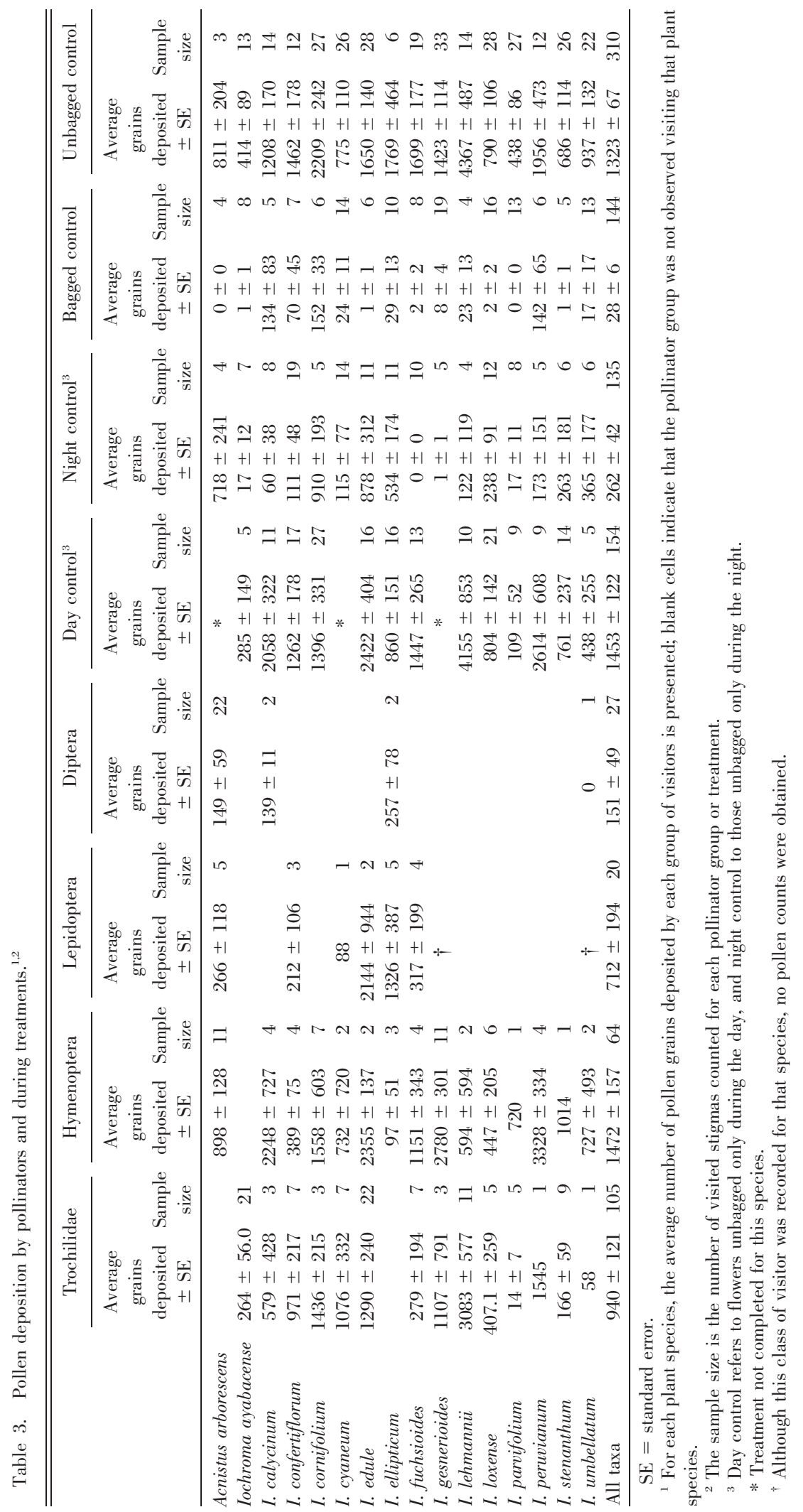


Published in the Annals of the Missouri Botanical Garden (2008) 95: 600-617.

\begin{tabular}{|c|c|c|c|c|c|c|c|c|c|c|c|c|c|c|c|c|}
\hline & Species (site) & 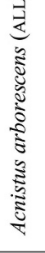 & 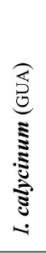 & 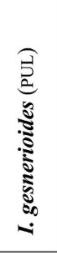 & 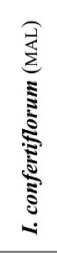 & 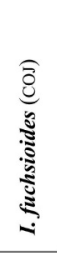 & 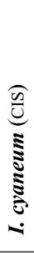 & 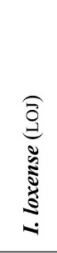 & 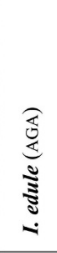 & 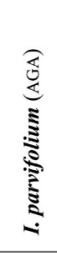 & 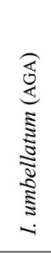 & 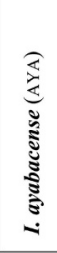 & 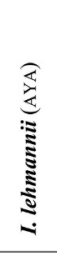 & 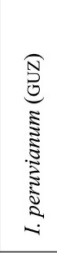 & 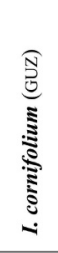 & 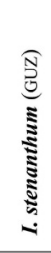 \\
\hline & Iochroma ellipticum (GAL) & 0 & 0 & 0 & 0 & 0 & 0 & 0 & 0 & 0 & 0 & 0 & 0 & 0 & 0 & 0 \\
\hline & Acnistus arborescens (ALL) & & 0 & 0.06 & 0.02 & 0.09 & 0 & 0.01 & 0.01 & 0.08 & 0.11 & 0 & 0.01 & 0.11 & 0.03 & 0.01 \\
\hline N. ECU & I. calycinum (GUA) & & & 0.02 & 0 & 0.07 & 0 & 0 & 0 & 0 & 0 & 0 & 0 & 0 & 0 & 0 \\
\hline & I. gesnerioides $(\mathrm{PUL})$ & & & & 0.26 & 0.09 & 0 & 0.01 & 0.19 & 0.23 & 0.31 & 0.24 & 0.25 & 0.31 & 0.28 & 0.26 \\
\hline$C$ ECU & I. confertiflorum (MAL) & & & & & 0.39 & 0 & 0.01 & 0.19 & 0.19 & 0.43 & 0.41 & 0.42 & 0.43 & 0.30 & 0.42 \\
\hline C. LCU & I. fuchsioides $(\mathrm{COJ})$ & & & & & & 0 & 0.01 & 0.01 & 0.08 & 0.09 & 0 & 0.01 & 0.09 & 0.03 & 0.01 \\
\hline S $5 C H$ & I. cyaneum (CIS) & & & & & & & 0.72 & 0 & 0 & 0 & 0.17 & 0.17 & 0 & 0.17 & 0.17 \\
\hline S. ECU & I. loxense (LOJ) & & & & & & & & 0.01 & 0.01 & 0.01 & 0 & 0.01 & 0.01 & 0.01 & 0.01 \\
\hline \multirow{8}{*}{ N. PER } & I. edule (AGA) & & & & & & & & & 0.76 & 0.20 & 0.19 & 0.22 & 0.22 & 0.19 & 0.22 \\
\hline & I. parvifolium $(\mathrm{AGA})$ & & & & & & & & & & 0.25 & 0.17 & 0.18 & 0.27 & 0.20 & 0.18 \\
\hline & I. umbellatum $(\mathrm{AGA})$ & & & & & & & & & & & 0.48 & 0.44 & 0.88 & 0.31 & 0.53 \\
\hline & I. ayabacense (AYA) & & & & & & & & & & & & 0.96 & 0.44 & 0.28 & 0.48 \\
\hline & I. lehmannii (AYA) & & & & & & & & & & & & & 0.44 & 0.31 & 0.70 \\
\hline & I. peruvianum (GUZ) & & & & & & & & & & & & & \multirow{3}{*}{\multicolumn{2}{|c|}{0.31}} & 0.46 \\
\hline & I. cornifolium (GUZ) & & & & & & & & & & & & & & & 0.55 \\
\hline & I. stenanthum (GUZ) & & & & & & & & & & & & & & & \\
\hline
\end{tabular}

Figure 2. Pairwise similiarity in pollinator assemblage across Iochroma species. The names of the principally hummingbird-pollinated taxa are in boldface. Study site names are abbreviated as follows: AGA = Agallpampa, AYA = Ayabaca, CIS $=$ Cisne, COJ $=$ Cojitambo, GUZ = Guzmango, LOJ = Loja, MAL = Malpote, and PUL = Pululahua. Regions are abbreviated as follows: N. ECU = northern Ecuador, C. ECU = central Ecuador, S. ECU = southern Ecuador, and N. PER $=$ northern Peru. Values for taxa in the same region are boxed in thin black lines, and taxa in sympatry are boxed in thick black lines. Shading of cells denotes degree of similarity.

significant preference for a particular species, although, in some cases, for the less rewarding species. For instance, over the course of three bouts, A. melanogenys visited 49 flowers on the low-reward Iochroma umbellatum and no flowers on I. edule $(P<0.001)$. Insect visits were typically too infrequent to show any significant pattern, but often they tended toward the less rewarding species (Table 4).

We also considered the movement of individual pollinators between these sympatric plant pairs. Although pollinator species could be observed visiting multiple sympatric plant species, we rarely saw movement between species by individual pollinators (Fig. 3). For instance, when observing an individual of Iochroma cyaneum and I. lehmannii side by side, only one of 60 visits involved movement from I. lehmannii to I. cyaneum and five involved movement in the reverse direction. The smaller hummingbirds (mentioned above) were largely responsible for these occasional interspecific movements. However, the overall rarity of interspecific movements between these individual plant pairs points to some individual-level pollinator fidelity. Due to the sparse distribution of Iochroma plants, we could not explore the frequency with which individual pollinators continued to be constant to a particular species after moving beyond the observed pairs.

\section{POLLEN DEPOSITION AND POLLINATOR IMPORTANCE}

Results from the bagged and unbagged controls suggested that the study species require biotic pollination. Styles from bagged flowers typically had very few pollen grains, but in three cases (Iochroma calycinum, I. cornifolium, and I. peruvianum) they had larger loads, with means of 134, 152, and 142 grains, respectively (Table 3 ). These loads, which are small relative to those typically on visited flowers, could be due to very small insects penetrating the mesh, but were more likely due to self-pollen deposited during anthesis. If the observed loads in bagged flowers of I. cornifolium, I. peruvianum, and $I$. calycinum are indeed self-pollen, they might not result in fertilization as crossing studies indicate that most Iochroma species are self-incompatible (Smith \& Baum, 2007).

Comparison of the night- and day-bagged flowers indicated that, on average, 5.5 times more pollen was deposited during the day (0600-1900 hr.) than during the night (1900-0600 hr.; Table 3). In three species, Iochroma ellipticum, I. umbellatum, and I. cornifolium, pollen tube counts for the night-exposed flowers were greater than $50 \%$ that of day-exposed flowers. Iochroma ellipticum received the most visits during the 
Published in the Annals of the Missouri Botanical Garden (2008) 95: 600-617.

Copyright 2008, Missouri Botanical Garden. Used by permission. DOI: 10.3417/2007037.

Volume 95, Number 4

2008
Smith et al.

Pollination Biology of lochroma

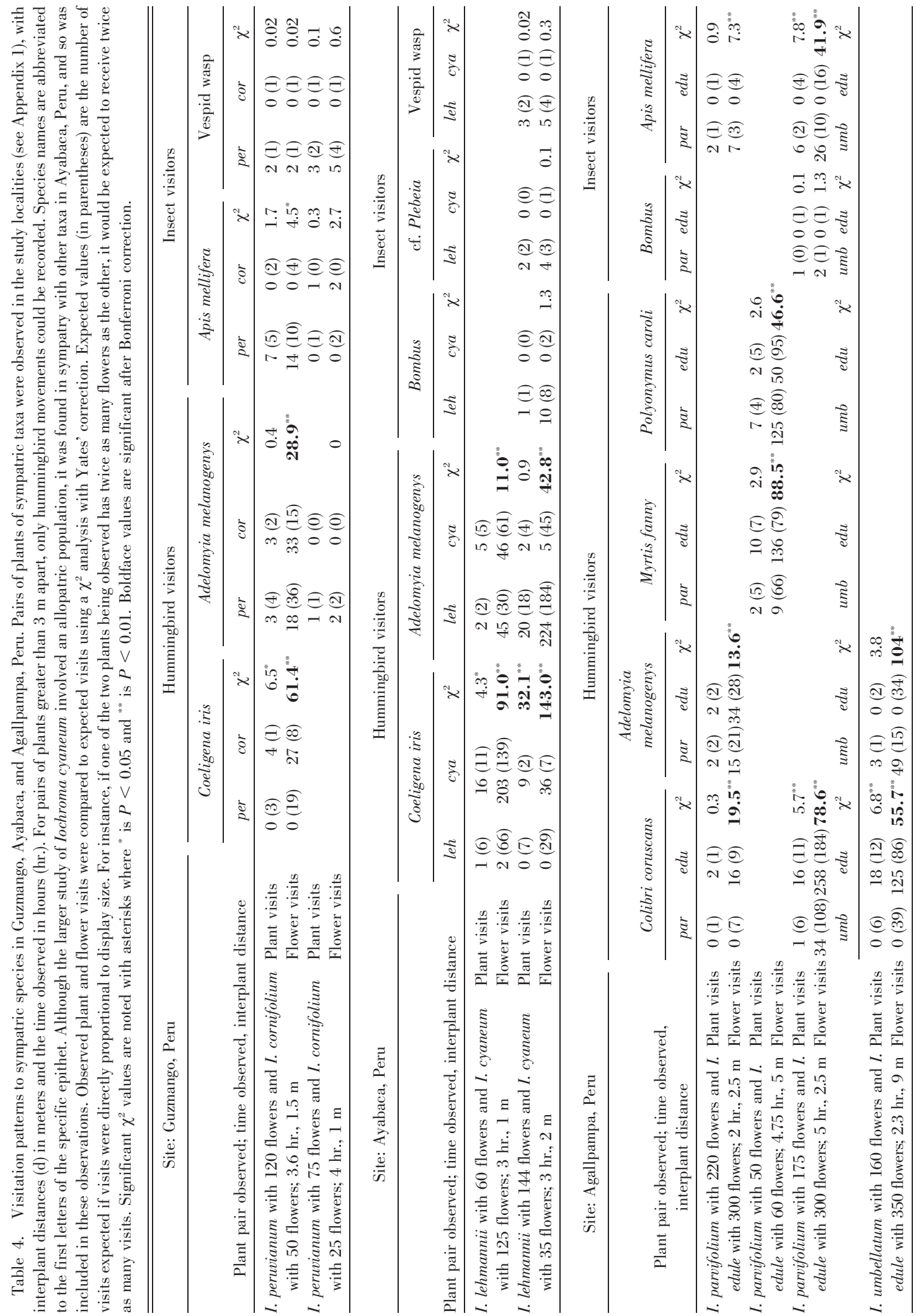



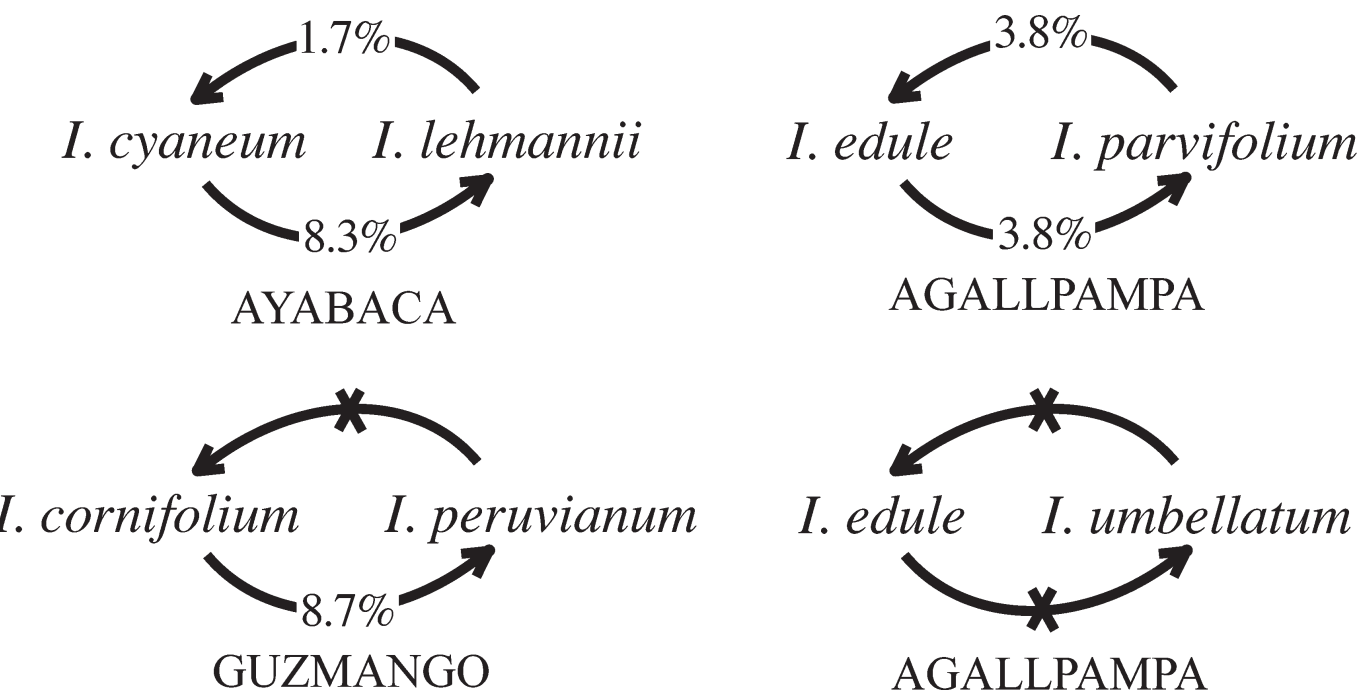

Figure 3. Observed interspecific pollinator movements among sympatric species in mixed populations. Arrows indicate percentage of interspecific movement observed between pairs of individual plants from different species, and crossed arrows indicate no observed interspecific pollinator movement. Sites where pairs were observed are given below pairs in capital letters. The percentage between Iochroma peruvianum and I. cornifolium is based on data from 23 visits to two pairs of plants, between I. lehmannii and I. cyaneum on 60 visits to two pairs of plants, I. edule and I. parvifolium on 52 visits to three pairs of plants, and I. edule and I. umbellatum on 21 visits on one pair of plants. Display sizes for these pairs are given in Table 4.

evening period (data not shown); thus, it was not surprising to find substantial night pollination in this species. Although no evening visits were observed for $I$. umbellatum, it could be visited by the same night-flying moths that visited the sympatric I. edule in the evening. It is unclear what could account for the night pollination in I. cornifolium, but the pollen loads (large relative to bagged flowers and comparable to visited flowers) implicate unidentified, nocturnally active animal visitors. Overall, however, the relatively small amounts of nocturnal pollen deposition in most taxa provide assurance that our largely diurnal pollinator observations covered most of the pollinator activity.

Thirty-four of the 47 pollinator species observed during the study visited virgin (previously bagged) flowers, allowing for estimation of pollen deposition. Visits by all species but one (an unidentified syrphid fly) resulted in pollen deposition (data not shown). Overall, hymenopterans deposited more pollen per visit on average than other classes of pollinators (Table 3). Dipteran visits resulted in the smallest deposition, on average (Table 3). Considering that the flowers have 50 to 500 ovules per flower (depending on species; Table 5), our deposition estimates suggest that single visits by most pollinator classes, except for dipterans, would result in enough pollen deposition to potentially fertilize all of the ovules. For instance, the average hummingbird visit deposited 264 viable pollen grains on a stigma of Iochroma ayabacense and, since this species has on average 124 ovules per flower, a single visit could potentially fertilize all the ovules.

Combining pollen deposition (quality) with visitation rate (quantity), we estimated the importance of each class of pollinators. For Iochroma gesnerioides and I. umbellatum, pollen counts were not available for the lepidopteran visitors. In the case of $I$. gesnerioides, we used the counts from its closest relative, I. fuchsioides, to estimate lepidopteran importance. For I. umbellatum, we used the average lepidopteran pollen deposition from I. confertiflorum, because for these two species, a hesperid butterfly species was the sole lepidopteran visitor. In this pollinator importance estimation, we scaled pollen deposition to equal the proportion of ovules potentially fertilized by a single visit. Since this proportion was 1.0 in most cases, pollinator importance values were similar to relative visitation (Table 5) as in Olsen (1997). Thus, hummingbirds appeared to be the most important pollinators for most Iochroma species, with only a few having either mixed bird-insect pollination or exclusively insect pollination (Table 5).

\section{DISCUSSION}

\section{SPATIO-TEMPORAL CONSIDERATIONS}

Interactions between plants and their pollinators are subject to temporal variation within a day, within a season, and across years (Herrera, 1988; Schemske \& 
Published in the Annals of the Missouri Botanical Garden (2008) 95: 600-617.

Copyright 2008, Missouri Botanical Garden. Used by permission. DOI: 10.3417/2007037

Volume 95, Number 4

Smith et al.

Table 5. Relative visitation rates and pollinator importance.

\begin{tabular}{|c|c|c|c|c|c|c|c|c|c|c|c|c|c|}
\hline \multirow[b]{2}{*}{ Species } & \multirow{2}{*}{$\begin{array}{c}\text { Average } \\
\text { ovules per } \\
\text { flower } \pm \mathrm{SE}\end{array}$} & \multicolumn{4}{|c|}{$\begin{array}{l}\text { Scaled pollen } \\
\text { deposition }^{1}\end{array}$} & \multicolumn{4}{|c|}{$\begin{array}{l}\text { Relative flower visitation } \\
\text { rates }^{2}\end{array}$} & \multicolumn{4}{|c|}{$\begin{array}{l}\text { Relative pollinator } \\
\text { importance }^{3}\end{array}$} \\
\hline & & Tro & Hym & Lep & Dip & Tro & Hym & Lep & Dip & Tro & Hym & Lep & Dip \\
\hline Acnistus arborescens & $52.0 \pm 3.5$ & - & 1 & 1 & 1 & 0 & 0.19 & 0.21 & 0.60 & 0 & 0.19 & 0.21 & 0.60 \\
\hline Iochroma ayabacense & $123.5 \pm 13.1$ & 1 & - & - & - & 1.00 & 0 & 0 & 0 & 1.00 & 0 & 0 & 0 \\
\hline I. calycinum & $488.0 \pm 29.3$ & 1 & 1 & - & 0.28 & 0.65 & 0.17 & 0 & 0.18 & 0.74 & 0.20 & 0.00 & 0.06 \\
\hline I. confertiflorum & $152.3 \pm 15.1$ & 1 & 1 & 1 & - & 0.78 & 0.19 & 0.03 & 0 & 0.78 & 0.19 & 0.03 & 0 \\
\hline I. cornifolium & $471.0 \pm 22.6$ & 1 & 1 & - & - & 0.96 & 0.04 & 0 & 0 & 0.96 & 0.04 & 0 & 0 \\
\hline I. cyaneum & $368.7 \pm 20.1$ & 1 & 1 & 0.24 & - & 0.80 & 0.13 & 0.07 & 0 & 0.84 & 0.14 & 0.02 & 0 \\
\hline I. edule & $414.7 \pm 15.6$ & 1 & 1 & 1 & - & 0.98 & 0.01 & 0.01 & 0 & 0.99 & 0.01 & 0.01 & 0 \\
\hline I. ellipticum & $53.4 \pm 13.0$ & - & 1 & 1 & 1 & 0 & 0.38 & 0.38 & 0.23 & 0 & 0.38 & 0.38 & 0.23 \\
\hline I. fuchsioides & $462.7 \pm 7.6$ & 0.60 & 1 & 0.69 & 0 & 0.77 & 0.16 & 0.06 & 0 & 0.70 & 0.24 & 0.07 & 0 \\
\hline I. gesnerioides & $264.7 \pm 19.8$ & 1 & 1 & 1 & - & 0.90 & 0.06 & 0.04 & 0 & 0.90 & 0.06 & 0.04 & 0 \\
\hline I. lehmannii & $69.3 \pm 5.6$ & 1 & 1 & - & - & 0.99 & 0.01 & 0 & 0 & 0.99 & 0.01 & 0 & 0 \\
\hline I. loxense & $254.7 \pm 21.7$ & 1 & 1 & - & - & 0.89 & 0.11 & 0 & 0 & 0.89 & 0.11 & 0 & 0 \\
\hline I. parvifolium & $69.1 \pm 6.9$ & 0.21 & 1 & - & - & 0.92 & 0.08 & 0 & 0 & 0.70 & 0.30 & 0 & 0 \\
\hline I. peruvianum & $230.3 \pm 11.6$ & 1 & 1 & 0 & 0 & 0.44 & 0.56 & 0 & 0 & 0.44 & 0.56 & 0 & 0 \\
\hline I. stenanthum & $146.0 \pm 12.5$ & 1 & 1 & - & - & 0.99 & 0.01 & 0 & 0 & 0.99 & 0.01 & 0 & 0 \\
\hline I. umbellatum & $134.3 \pm 7.2$ & 1 & 1 & 1 & 0 & 0.52 & 0.47 & $4 \times 10^{-3}$ & 0.01 & 0.32 & 0.67 & 0.01 & 0 \\
\hline
\end{tabular}

Horvitz, 1989; Ivey et al., 2003; Price et al., 2005). Here, we sampled across the times of the day, but we did not sample in multiple years or times of the year and each study took place during a three- to five-day period. The issue of temporal variation is mitigated by the fact all studies took place in the same season (the rainy season), during which weather conditions did not vary substantially from day to day. Also, the pollinator fauna in the study areas are resident, as opposed to migratory (Greenewalt, 1960), and, thus, might be expected to shift less from year to year. Casual observations in the same locality across years (S. D. Smith, unpublished data) showed some variation in the animal species visiting a particular Iochroma species, but not in the broad class of pollinator species (e.g., bird or insect). Associations of plants with classes of pollinators are probably more robust across time than the specific composition of the pollinator assemblage.

Plant-pollinator associations may also vary across spatial scales, e.g., across sites (Boyd, 2004; Price et al., 2005) or along environmental gradients (Scobell \& Scott, 2002; Herrera, 2005). Here, we have conducted studies of each species at a single site. Observations of several study taxa in other sites suggested that relative visitation of different classes of pollinators is similar across the species range despite variation in pollinator fauna (S. D. Smith, pers. obs.). For instance, in El Cisne, Ecuador, Iochroma cyaneum is mostly visited by the hummingbird Amazilia amazilia Lesson, whereas in Ayabaca, Peru, it is mainly visited by the hummingbirds Coeligena iris and Adelomyia melanogenys. Thus, while pollinator composition may vary across sites, I. cyaneum appears to be principally pollinated by hummingbirds across its range.

\section{FLORAL DIVERSITY AND POLLINATOR RELATIONSHIPS}

One goal in undertaking this study was to determine if the floral diversity in Iochroma corresponds to a diverse set of pollinator systems. At the broadest level, we observed three basic modes of pollination (bird, mixed bird/insect, and insect pollinated). Unlike other Andean taxa for which comparative pollination studies have been undertaken (Kay \& Schemske, 2003; Pérez et al., 2006), pollination systems in Iochroma appeared only weakly related to floral differences (see also Smith et al., 2008). The insect-pollinated taxa Acnistus arborescens and I. ellipticum were both white, scented, and offered a low reward, but varied in shape and size (Fig. 1). The mixed bird-/insectpollinated species $I$. peruvianum and I. umbellatum differed in flower color (one green, one orange), but shared two traits, small flowers and intermediate rewards (on a per-plant basis) (Table 1). The greatest floral variation was observed among the 12 birdpollinated taxa, whose flower colors included red, white, yellow, blue, and purple and whose corolla size varied nearly three-fold (Fig. 1). One common feature among bird-pollinated species, however, was a large 
nectar reward; all hummingbird-pollinated taxa had higher rewards than the mixed or exclusively insectpollinated taxa (see also Smith et al., 2008). This observation is in accord with other studies showing that the amount of reward is more important than visual cues (e.g., flower color) in determining hummingbird visitation (Collias \& Collias, 1968; Stiles, 1976; Melendez-Ackerman et al., 1997).

We also considered the possibility that the diversity of flower form among species sharing the same pollination system could reflect lower-level specialization, e.g., for particular pollinator species. However, we found no evidence to support such an explanation. A single hummingbird or insect species (e.g., Adelomyia melanogenys and Apis mellifera L.) was observed visiting multiple species of Iochroma, and, conversely, a single plant species was visited by multiple pollinator species (Appendix 2). For example, an average bird-pollinated Iochroma species was visited by 2.4 hummingbird species, and an average insect-pollinated species by 8.0 insect species. Furthermore, measurements of pollen deposition suggested that the vast majority of these visitors were effective pollinators. Thus, it appears that Iochroma species do not have tightly coevolved, specialized pollination systems.

Despite visits by many pollinator species, it is possible that a given Iochroma species could be specialized on a guild or functional group of pollinators, which collectively explain the particular floral traits seen. If this were the case, one might expect a lack of pollinator sharing among geographically proximate but florally distinct Iochroma species. However, our analysis of pollinator assemblage similarity showed that diverse taxa from the same geographic region and from the same study site shared pollinator species significantly more often than those from different regions or sites (Fig. 2). This is consistent with the idea that Iochroma species are generalists within a broad class (such as hummingbirds) and that they tend to be visited by whichever pollinator species are locally abundant.

\section{POLLINATOR BEHAVIOR AND REPRODUCTIVE ISOLATION}

The overlap in pollinator assemblage among sympatric taxa has significant implications for the maintenance of species boundaries. Considering that nearly all pollinators were capable of transferring loads of pollen in excess of the number of ovules on any given visit, any foraging bout that included visits to multiple species would almost certainly result in interspecific pollen flow. All sympatric species studied here shared at least two pollinator species, and some as many as four (Appendix 2), making interspecific pollen flow in sympatry potentially common. On the other hand, subtle differences in visitation rates and patterns appear to restrict interspecific pollen flow. First, PS values for sympatric taxa, even those with the same broad pollination system, were typically much lower than 1 (range, 0.20-0.96; mean, 0.51), reflecting differential visitation by pollinator species. Second, we observed that individual pollinators do not tend to move between sympatric species even when the plants are growing side by side (Fig. 3). This could be explained by individual preferences (Jones \& Reithel, 2001) or optimal foraging (Heinrich, 1976; Waser, 1986), but is perhaps better explained by territoriality. Areas of Iochroma sympatry contained several hummingbird species, including small birds (e.g., Adelomyia melanogenys and Polyonymus caroli) and larger birds (e.g., Colibri coruscans and Coeligena iris). As mentioned previously, smaller hummingbirds tended to visit less nectar-rewarding species in mixed populations, even though there is no mechanical barrier preventing them from retrieving nectar from the more rewarding species. Larger, more aggressive birds dominate the more rewarding species and defend individuals of the rewarding species from the smaller birds (Feinsinger \& Colwell, 1978; Stiles, 1981). One can envision that territorial behavior might prevent or reduce gene flow among plant species in mixed patches, and that this effect would be enhanced by differences in reward (Table 1). The combination of local spatial separation of populations, perhaps due to microhabitat specialization, and hummingbird territoriality might then reduce the potentially frequent interspecific pollen flow in sympatry. The low incidence of hybridization among sympatric Iochroma might reflect individual pollinator fidelity driven by interactions among hummingbirds, additional pre-fertilization mechanisms (e.g., pollen competition), and/or post-fertilization mechanisms. Although artificial interspecific crosses suggest wide crossability among Iochroma species (Smith \& Baum, 2007; S. D. Smith, unpublished data), none of the species pairs that grow in sympatry without observed hybrids have yet been examined. Thus, additional crossing studies and tests of hybrid fitness will be required to understand how Iochroma species coexist in northern Andean communities.

\section{Literature Cited}

Boyd, A. E. 2004. Breeding system of Macromeria viridiflora (Boraginaceae) and geographic variation in pollinator assemblages. Amer. J. Bot. 91: 1809-1813.

Campbell, D. R. \& A. F. Motten. 1985. The mechanism of competition for pollination between two forest herbs. Ecology 66: 554-563. 
Published in the Annals of the Missouri Botanical Garden (2008) 95: 600-617.

Cocucci, A. 1999. Evolutionary radiation in Neotropical Solanaceae. Pp. 9-22 in M. Nee, D. E. Symon, R. N. Lester \& J. P. Jessop (editors), Solanaceae IV: Advances in Biology and Utilization. Royal Botanic Gardens, Kew, United Kingdom.

Collias, N. E. \& E. C. Collias. 1968. Anna's Hummingbirds trained to select different colors in feeding. Condor 70 273-274.

Dafni, A. 1992. Pollination Ecology: A Practical Approach. Oxford University Press, Oxford, United Kingdom.

Faegri, K. \& L. van der Pijl. 1966. The Principles of Pollination Ecology. Pergamon Press, Oxford, United Kingdom.

Feinsinger, P. \& R. K. Colwell. 1978. Community organization among Neotropical nectar-feeding birds. Amer. Zool. 18: 779-795.

Fenster, C. B., W. S. Armbruster, P. Wilson, M. R. Dudash \& J. D. Thomson. 2004. Pollination syndromes and floral specialization. Annual Rev. Ecol. Syst. 35: 375-403.

Gentry, A. H. 1982. Neotropical floristic diversity-Phytogeographical connections between Central and South America, Pleistocene climatic fluctuations, or an accident of the Andean orogeny. Ann. Missouri Bot. Gard. 69: 557-593.

Greenewalt, C. H. 1960. Hummingbirds. Doubleday and Co., Garden City, New Jersey.

Heinrich, B. 1976. Foraging specializations of individual bumblebees. Ecol. Monogr. 46: 105-128.

Herrera, C. M. 1987. Components of pollinator 'quality': Comparative analysis of a diverse insect assemblage. Oikos 50: 79-90.

1988. Variation in mutualisms: The spatio-temporal mosaic of a pollinator assemblage. Biol. J. Linn. Soc. 35 $95-125$.

. 2005. Plant generalization on pollinators: Species property or local phenomenon? Amer. J. Bot. 92: 13-20.

Hunziker, A. T. 2001. The genera of Solanaceae. A.R.G. Ganter Verlag K.-G., Ruggell, Liechtenstein.

Ivey, C. T., P. Martinez \& R. Wyatt. 2003. Variation in pollinator effectiveness in swamp milkweed, Asclepias incarnata (Apocynaceae). Amer. J. Bot. 90: 214-225.

Janzen, D. H. 1973. Comments on host-specificity of tropical herbivore and its relevance to species richness. Pp. 201211 in V. H. Heywood (editor), Taxonomy and Ecology. Academic Press, New York.

Johnson, S. D. \& K. E. Steiner. 2000. Generalization versus specialization in plant pollination systems. Trends Ecol. Evol. 15: 140-143.

Jones, C. E. 1978. Pollinator constancy as a pre-pollination isolating mechanism between sympatric species of Cercidium. Evolution 32: 189-198.

Jones, K. N. \& J. S. Reithel. 2001. Pollinator-mediated selection on a flower color polymorphism in experimental populations of Antirrhinum (Scrophulariaceae). Amer. J. Bot. 88: 447-454.

Kaiser, R. 2000. Scents from rain forests. Chimia 54: 346-363.

Kay, K. M. \& D. W. Schemske. 2003. Pollinator assemblages and visitation rates for 11 species of Neotropical Costus (Costaceae). Biotropica 35: 198-207.

_ $\&$. 2004. Geographic patterns in plantpollinator mutualistic network: Comment. Ecology 85: 875-878.

Kearns, C. A. \& D. W. Inouye. 1993. Techniques for Pollination Biologists. University of Colorado Press, Boulder.

Kohn, J. R. \& N. M. Waser. 1985. The effect of Delphinium nelsonii pollen on seed set in Ipomopsis aggregata, a competitor for hummingbird pollination. Amer. J. Bot. 72 1144-1148.
Lagerheim, G. 1891. Zur biologie de Jochroma macrocalyx. Deutsch. Bot. Ges. 9: 348-351.

Luteyn, J. L. 2002. Diversity, adaptation, and endemism in Neotropical Ericaceae: Biogeographical patterns in the Vaccinieae. Bot. Rev. 68: 55-87.

Martin, F. W. 1959. Staining and observing pollen tubes in the style by means of fluorescence microscopy. Stain Technol. 34: 125-128.

Mayfield, M. M., N. M. Waser \& M. V. Price. 2001. Exploring the 'most effective pollinator principle' with complex flowers: Bumblebees and Ipomopsis aggregata. Ann. Bot. 88: 591-596.

Melendez-Ackerman, E., D. R. Campbell \& N. M. Waser. 1997. Hummingbird behavior and mechanisms of selection on flower color in Ipomopsis. Ecology 78: 2532-2541.

Muchhala, N. 2006. The pollination biology of Burmeistera (Campanulaceae): Specialization and syndromes. Amer. J. Bot. 93: 1081-1089.

Olesen, J. M. \& P. Jordano. 2002. Geographic patterns in plantpollinator mutualistic networks. Ecology 83: 2416-2424

Ollerton, J. \& L. Cranmer. 2002. Latitudinal trends in plantpollinator interactions: Are tropical plants more specialised? Oikos 98: 340-350.

Olsen, K. M. 1997. Pollination effectiveness and pollinator importance in a population of Heterotheca subaxillaris (Asteraceae). Oecologia 109: 114-121.

Pérez, F., M. T. K. Arroyo, R. Medel \& M. A. Hershkovitz. 2006. Ancestral reconstruction of flower morphology and pollination systems in Schizanthus (Solanaceae). Amer. J. Bot. 93: 1029-1038.

Perret, M., A. Chautems, R. Spichiger, M. Peixoto \& V. Savolainen. 2001. Nectar sugar composition in relation to pollination syndromes in Sinningieae (Gesneriaceae). Ann. Bot. 87: 267-273.

Price, M. V., N. M. Waser, R. E. Irwin, D. R. Campbell \& A K. Brody. 2005. Temporal and spatial variation in pollination of a montane herb: A seven-year study. Ecology 86: 2106-2116.

Schemske, D. W. 1981. Floral convergence and pollinator sharing in two bee-pollinated tropical herbs. Ecology 62 : 946-954.

- \& N. Brokaw. 1981. Treefalls and the distribution of understory birds in a tropical forest. Ecology 62: 938-945.

\& C. C. Horvitz. 1984. Variation among floral visitors in pollination ability; a precondition for mutualism specialization. Science 225: 519-521.

-1 . 1989. Temporal variation in selection on a floral character. Evolution 43: 461-465.

Scobell, S. A. \& P. E. Scott. 2002. Visitors and floral traits of a hummingbird-adapted cactus (Echinocereus coccineus) show only minor variation along an elevational gradient. Amer. Midl. Naturalist 147: 1-15.

Silander, J. A. \& R. B. Primack. 1978. Pollination intensity and seed set in the evening primrose (Oenothera fruticosa). Amer. Midl. Naturalist 100: 213-216.

Smith, S. D. 2006. Floral Diversification and Pollination Biology of the Andean Clade Iochrominae (Solanaceae) Ph.D. Thesis, University of Wisconsin, Madison.

\& D. A. Baum. 2006. Phylogenetics of the florally diverse Andean clade Iochrominae (Solanaceae). Amer. J. Bot. 93: 1140-1153.

— \& - 2007. Systematics of Iochrominae (Solanaceae): Patterns in floral diversity and interspecific crossability. Acta Hort. 745: 241-254.

, C. Ané \& D. A. Baum. 2008. The role of pollinator shifts in the floral diversification of Iochroma (Solanaceae). Evolution 62: 793-806. 
Published in the Annals of the Missouri Botanical Garden (2008) 95: 600-617.

Copyright 2008, Missouri Botanical Garden. Used by permission. DOI: 10.3417/2007037.

614

Annals of the

Missouri Botanical Garden

Stiles, F. G. 1976. Taste preferences, color preferences, and flower choice in hummingbirds. Condor 78: 1026.

1981. Geographical aspects of bird-flower coevolution, with particular reference to Central America. Ann. Missouri Bot. Gard. 68: 323-351.

Waser, N. M. 1986. Flower constancy: Definition, cause and measurement. Amer. Naturalist 127: 593-603.
\& M. V. Price. 1983. Optimal and actual outcrossing in plants, and the nature of plant-pollinator interaction. Pp. 341-359 in C. E. Jones \& R. J. Little (editors), Handbook of Experimental Pollination Biology. Van Nostrand Reinhold, New York.

Weigend, M. 2002. Observations on the biogeography of the Amotape-Huancabamba zone in northern Peru. Bot. Rev. 68: $38-54$. 
Published in the Annals of the Missouri Botanical Garden (2008) 95: 600-617.

Copyright 2008, Missouri Botanical Garden. Used by permission. DOI: 10.3417/2007037.

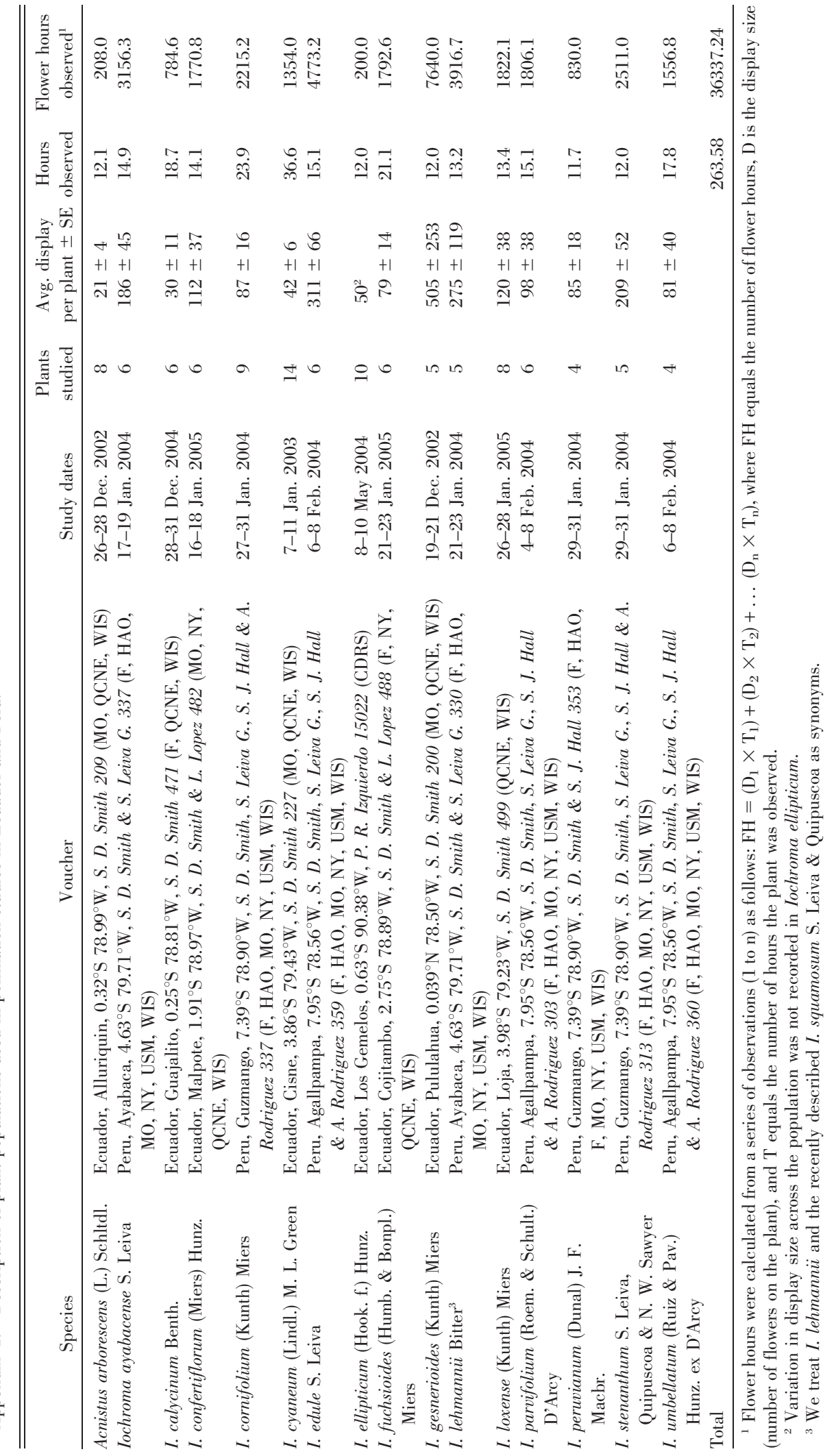


Published in the Annals of the Missouri Botanical Garden (2008) 95: 600-617.

Appendix 2. Pollinator taxa and visitation rates. Animals are listed by order and identified to species when possible, and only legitimate pollinators (which made contact with the reproductive organs) are included. Each unidentified visitor is given a unique number within its taxonomic group, and these identifiers are shared across plant species. For example, both Iochroma cornifolium and I. peruvianum were visited by Vespidae, sp. indet. 1. Only pollinators observed during the individual species studies are included; additional visitors observed during subsequent experiments (e.g., Myrtis fanny; Table 5) are not listed here. For each pollinator, plant and flower visitation rates (per flower hour) are listed (separated by a slash).

\begin{tabular}{|c|c|c|}
\hline \multirow[t]{7}{*}{ Acnistus arborescens } & Hymenoptera & $\begin{array}{l}\text { Apidae, Apis mellifera } \text { L., } 0.014 / 0.048 \\
\text { sp. indet. } 1,0.010 / 0.034\end{array}$ \\
\hline & Lepidoptera & sp. indet. $2,0.010 / 0.091$ \\
\hline & Diptera & Syrphidae, sp. indet. 1, 0.024/0.058 \\
\hline & & Tipulidae, sp. indet. $1,0.043 / 0.115$ \\
\hline & & sp. indet. $1,0.019 / 0.048$ \\
\hline & & sp. indet. $2,0.005 / 0.019$ \\
\hline & & sp. indet. $3,0.005 / 0.014$ \\
\hline \multirow[t]{2}{*}{ Iochroma ayabacense } & Apodiformes & Trochilidae, Adelomyia melanogenys Fraser, 0.005/0.089 \\
\hline & & Trochilidae, Coeligena iris Gould, 0.005/0.097 \\
\hline \multirow[t]{6}{*}{ I. calycinum } & Apodiformes & Trochilidae, Coeligena torquata Boissoneau, 0.001/0.013 \\
\hline & & Trochilidae, Phaethornis Swainson, 0.001/0.045 \\
\hline & & Trochilidae, sp. indet. $1,0.005 / 0.033$ \\
\hline & Hymenoptera & Apidae, Parapartamona vittigera Moure, 0.001/0.001 \\
\hline & & Apidae, Plebia sp. 2, 0.017/0.023 \\
\hline & Diptera & Drosophilidae, sp. indet. $1,0.025 / 0.025$ \\
\hline \multirow[t]{6}{*}{ I. confertiflorum } & Apodiformes & Trochilidae, Adelomyia melanogenys, 0.007/0.090 \\
\hline & & Trochilidae, Heliangelus viola Gould, 0.004/0.082 \\
\hline & Hymenoptera & Apidae, Apis mellifera, 0.002/0.005 \\
\hline & & Apidae, Parapartamona vittigera, $0.014 / 0.028$ \\
\hline & & Halictidae, Caenohalictus sp. indet. 1, 0.008/0.010 \\
\hline & Lepidoptera & Hesperidae, sp. indet. 1, 0.002/0.006 \\
\hline \multirow[t]{4}{*}{ I. cornifolium } & Apodiformes & Trochilidae, Adelomyia melanogenys, 0.004/0.051 \\
\hline & & Trochilidae, Coeligena iris, $0.008 / 0.125$ \\
\hline & Hymenoptera & Apidae, Apis mellifera, 0.003/0.006 \\
\hline & & Vespidae, sp. indet. 1, 0.001/0.001 \\
\hline \multirow[t]{5}{*}{ I. cyaneum } & Apodiformes & Trochilidae, Amazilia amazilia Lesson, 0.032/0.188 \\
\hline & & Trochilidae, Coeligena iris, 0.008/0.049 \\
\hline & Hymenoptera & Vespidae, Polybia sp. indet., 0.027/0.040 \\
\hline & Lepidoptera & Sphingidae, sp. indet. $1,0.001 / 0.007$ \\
\hline & & sp. indet. $1,0.007 / 0.014$ \\
\hline \multirow[t]{5}{*}{ I. edule } & Apodiformes & Trochilidae, Adelomyia melanogenys, 0.002/0.033 \\
\hline & & Trochilidae, Colibri coruscans Gould, 0.003/0.031 \\
\hline & & Trochilidae, Polyonymus caroli Bourcier, 0.005/0.089 \\
\hline & Hymenoptera & Apidae, Apis mellifera, $0.0004 / 0.001$ \\
\hline & Lepidoptera & Noctuidae, sp. indet. 1, 0.0003/0.001 \\
\hline \multirow[t]{8}{*}{ I. ellipticum } & Hymenoptera & Formicidae, Paratrechina, 0.002/0.002 \\
\hline & & Formicidae, Wasmannia auropunctata Roger, 0.002/0.002 \\
\hline & & Vespidae, Pachodynerus galapagoensis Williams, 0.003/0.005 \\
\hline & Lepidoptera & Geometridae, Oxydia lignata Warren, 0.002/0.002 \\
\hline & & Noctuidae, Agrotisia williamsi Schaus, 0.002/0.002 \\
\hline & & Noctuidae, sp. indet. $2,0.002 / 0.003$ \\
\hline & & sp. indet. $3,0.002 / 0.002$ \\
\hline & Diptera & Syrphidae, Xanthandrus agonis Walker, 0.005/0.005 \\
\hline \multirow[t]{5}{*}{ I. fuchsioides } & Apodiformes & Trochilidae, Coeligena torquata, 0.001/0.021 \\
\hline & & Trochilidae, Heliangelus viola Gould, 0.008/0.214 \\
\hline & Hymenoptera & Apidae, Apis mellifera, 0.004/0.027 \\
\hline & & Halictidae, Caenohalictus sp. 2, 0.016/0.022 \\
\hline & Lepidoptera & Danaidae, sp. indet. $1,0.003 / 0.020$ \\
\hline
\end{tabular}


Published in the Annals of the Missouri Botanical Garden (2008) 95: 600-617.

Copyright 2008, Missouri Botanical Garden. Used by permission. DOI: 10.3417/2007037.

Volume 95, Number 4

Smith et al.

Appendix 2. Continued.

\begin{tabular}{|c|c|c|}
\hline \multirow[t]{6}{*}{ I. gesnerioides } & Apodiformes & Trochilidae, Adelomyia melanogenys, 0.002/0.040 \\
\hline & & Trochilidae, Coeligena torquata, 0.0001/0.004 \\
\hline & & Trochilidae, Boissonneaua flavescens Loddiges, 0.004/0.102 \\
\hline & & Trochilidae, sp. indet. 3, 0.0001/0.003 \\
\hline & Hymenoptera & Apidae, Apis mellifera, 0.001/0.010 \\
\hline & Lepidoptera & Sphingidae, sp. indet. 2, 0.001/0.006 \\
\hline \multirow[t]{4}{*}{ I. lehmannii } & Apodiformes & Trochilidae, Adelomyia melanogenys, 0.002/0.148 \\
\hline & & Trochilidae, Coeligena iris, 0.005/0.190 \\
\hline & Hymenoptera & Apidae, Apis mellifera, 0.001/0.003 \\
\hline & & Apidae, Plebeia, 0.0003/0.001 \\
\hline \multirow[t]{4}{*}{ I. loxense } & Apodiformes & Trochilidae, Amazilia amazilia, 0.017/0.251 \\
\hline & Hymenoptera & Apidae, Apis mellifera, 0.001/0.002 \\
\hline & & Colletidae, Chilicola cf. pedunculata, 0.005/0.005 \\
\hline & & Vespidae, Polybia, 0.016/0.024 \\
\hline \multirow[t]{6}{*}{ I. parvifolium } & Apodiformes & Trochilidae, Adelomyia melanogenys, 0.004/0.057 \\
\hline & & Trochilidae, Colibri coruscans, 0.001/0.001 \\
\hline & & Trochilidae, Polyonymus caroli, 0.010/0.230 \\
\hline & & Trochilidae, sp. indet. 2, 0.001/0.021 \\
\hline & Hymenoptera & Apidae, Apis mellifera, 0.007/0.027 \\
\hline & & Vespidae, sp. indet. 2, 0.001/0.001 \\
\hline \multirow[t]{3}{*}{ I. peruvianum } & Apodiformes & Trochilidae, Adelomyia melanogenys, 0.008/0.047 \\
\hline & Hymenoptera & Apidae, Apis mellifera, 0.021/0.055 \\
\hline & & Vespidae, sp. indet. 1, 0.004/0.005 \\
\hline \multirow[t]{3}{*}{ I. stenanthum } & Apodiformes & Trochilidae, Adelomyia melanogenys, 0.006/0.192 \\
\hline & & Trochilidae, Coeligena iris, 0.004/0.068 \\
\hline & Hymenoptera & Apidae, Apis mellifera, 0.002/0.004 \\
\hline \multirow[t]{6}{*}{ I. umbellatum } & Apodiformes & Trochilidae, Adelomyia melanogenys, 0.007/0.153 \\
\hline & & Trochilidae, Colibri coruscans, 0.001/0.001 \\
\hline & Hymenoptera & Apidae, Apis mellifera, $0.019 / 0.131$ \\
\hline & & Anthophoridae, Melissodes, $0.003 / 0.009$ \\
\hline & Lepidoptera & Hesperidae, sp. indet. 2, 0.001/0.001 \\
\hline & Diptera & Syrphidae, sp. indet. 2, 0.002/0.003 \\
\hline
\end{tabular}

